\title{
Application Of Preview, Question, Read, Reflect, Recite, Review (PQ4R) Methods To Improve Reading Skills
}

\section{Ayu Prasetyaningrum}

Universitas Sebelas Maret

Ayuprasetya3008@gmail.com

\section{Article History}

received 30/4/2021

revised 30/5/2021

accepted 30/6/2021

\begin{abstract}
This study aims to improve the reading comprehension skills of fourth grade students of SD Negeri 1 Ngadirojo Lor for the 2020/2021 academic year by applying the Preview, Question, Read, Reflect, Recite, Review (PQ4R) method. This research was structured using a qualitative approach with the type of Classroom Action Research (CAR) which was carried out in two cycles. Each cycle consists of two meetings. Each implementation consists of planning, implementing, observing, reflecting. The subjects studied were teachers and 15 grade IV students of SD Negeri 1 Ngadirojo Lor for the 2020/2021 academic year. Data was collected by using observation, interview, test, and documentation techniques. The validity of the data used are content validity, source triangulation, and technical triangulation. Analysis of the data using the interactive analysis model of Milles and Huberman. The results show that the application of the Preview, Question, Read, Reflect, Recite, Review (PQ4R) method can improve the reading comprehension skills of fourth grade students of SD Negeri 1 Ngadirojo Lor for the 2020/2021 school year.
\end{abstract}

Keywords: reading comprehension skills, Preview, Question, Read, Reflect, Recite, Review (PQ4R)

\section{Abstrak}

Penelitian ini bertujuan untuk meningkatkan keterampilan membaca pemahaman peserta didik kelas IV SD Negeri 1 Ngadirojo Lor tahun ajaran 2020/2021 dengan menerapkan metode Preview, Question, Read, Reflect, Recite, Review (PQ4R). Penelitian ini disusun menggunakan pendekatan kualitatif dengan jenis Penelitian Tindakan Kelas (PTK) yang dilaksanakan dengan dua siklus. Setiap siklus terdiri dari dua pertemuan. Setiap pelaksanaan terdiri dari perencanaan, pelaksanaan, pengamatan, refleksi. Subjek yang diteliti adalah guru dan 15 peserta didik kelas IV SD Negeri 1 Ngadirojo Lor tahun ajaran 2020/2021. Pengumpulan data dilakukan dengan teknik observasi, wawancara, tes, dan dokumentasi. Validitas data yang digunakan yaitu validitas isi, triangulasi sumber, dan triangulasi teknik. Analisis data menggunakan model analisis interaktif Milles dan Huberman. Hasil penelitian menunjukkan bahwa penerapan metode Preview, Question, Read, Reflect, Recite, Review (PQ4R) dapat meningkatkan keterampilan membaca pemahaman peserta didik kelas IV SD Negeri 1 Ngadirojo Lor tahun ajaran 2020/2021.

Kata kunci: keterampilan membaca pemahaman, metode Preview, Question, Read, Reflect, Recite, Review (PQ4R) 


\section{PENDAHULUAN}

Pada abad 21 membaca merupakan aspek penting yang harus dikuasai peserta didik. Membaca dilakukan menunjang aktivitas sehari-hari berbagai ilmu di dapatkan melalui membaca sehingga membaca sangat penting bagi peserta didik. Tak salah apabila membaca termasuk keterampilan dasar yang harus ditumbuhkembangkan pada pendidikan dasar.

Keterampilan membaca peserta didik menentukan keberhasilannya menguasai berbagai mata pelajaran. Keterampilan membaca akan menjadi bekal bagi peserta didik untuk memperoleh pengetahuan dan memahami banyak pokok bahasan. Oleh sebab itu, keterampilan membaca amat penting bagi peserta didik.

Kegiatan membaca merupakan proses memahami kelompok kata menjadi sebuah makna. Proses membaca dikatakan baik apabila pesan tersurat dan tersirat dalam bacaan dapat tersampaikan. Keterampilan membaca guna memahami keseluruhan isi bacaan ialah keterampilan membaca pemahaman. Keterampilan membaca di kelas IV sudah menginjak pada keterampilan membaca pemahaman. Menurut Tarigan (2008:58) keterampilan membaca pemahaman mencakup pemahaman pengertian sederhana, kecepatan membaca, pemahaman signifikan dan penilaian isi bacaan.

Luasnya wawasan peserta didik menentukan tingkat pemahaman yang akan didapatnya. Pengetahuan kebahasaan menjadi bekal peserta didik dalam kegiatan membaca, salah satunya adalah penguasaan kosa kata yang baik, dengan penguasaan kosa kata yang baik peserta didik mampu memahami arti kata, kalimat, atau paragraf dalam suatu bacaan untuk mengetahui maknanya.

Eskey (Saddhono \& Slamet, 2012) menemukan kesulitan dalam memahami isi bacaan karena kebiasaaan baca yang salah yaitu terlalu banyak memperhatikan butir demi butir informasi. Hal ini juga merupakan kebiasaan dan kesalahan yang paling sering dilakukan oleh peserta didik. Hazzard (dalam Suyitno, 2017:117) menyatakan bahwa membaca memberikan pengaruh yang signifikan terhadap keberhasilan belajar. Pembaca memperoleh informasi yang diperlukan untuk memenuhi kebutuhan tugas belajar mereka sehingga proses belajar membaca yang baik akan memainkan peran penting dalam mencapai kesuksesan dalam lingkup sekolah dan kehidupan.

Kurikulum 2013 dengan pembelajaran tematik yaitu merangkai beberapa mata pelajaran menjadi satu pembelajaran berdasarkan tema. Membaca pemahaman di kelas IV terdapat pada tema 8. Penilaian dalam keterampilan membaca pemahaman yaitu dengan menceritakan kembali teks cerita fiksi menggunakan bahasa sendiri. Menurut (Nurgiyantoro, 2017:414) terdapat lima indikator dalam menceritakan kembali yaitu pemahaman isi teks, ketepatan organisasi isi teks, ketepatan struktur kalimat, penulisan tanda baca dan penggunaan huruf kapital, dan ketepatan diksi, yang memiliki bobot masing-masing setiap indikator.

Berdasarkan hasil observasi peneliti menemukan beberapa faktor yang mempengaruhi masih rendahnya keterampilan membaca pemahaman pada peserta didik. Faktor-faktor tersebut ialah peserta didik kurang fokus saat berlangsungnya kegiatan membaca, hal ini menyebabkan rendahnya konsentrasi dan mempengaruhi daya serap peserta didik terhadap bacaan. Peserta didik masih ada yang belum bisa membaca sampai harus dituntun guru kelas dalam kegiatan membaca. Saat kegiatan pembelajaran berlangsung peserta didik kurang terlibat aktif karena pembelajaran berpusat pada guru dan guru belum menggunakan metode pembelajaran inovatif pada materi keterampilan membaca pemahaman, peserta didik hanya mendengarkan penjelasan dari guru sehingga muncul sikap bosan, tidak serius, dan mengantuk.

Wawancara dengan guru kelas dapat ditarik kesimpulan bahwa antusias peserta didik dalam kegiatan membaca kurang dan tingkat pemahaman peserta didik masih rendah. Mengacu pada hasil observasi dan hasil wawancara dapat ditarik kesimpulan bahwa keterampilan membaca pemahaman peserta didik kelas IV SD Negeri 1 
Ngadirojo Lor masih kurang. Hal ini juga dibuktikan dengan hasil pratindakan yang menunjukkan bahwa sebagian besar peserta didik belum memenuhi kriteria ketuntasan minimal (KKM). Kriteria ketuntasan minimal yang ditetapkan untuk keterampilan membaca pemahaman adalah 70 . Jumlah keseluruhan peserta didik kelas IV adalah 15 peserta didik. Perolehan skor tahap pratindakan sebanyak 2 peserta didik dinyatakan kategori terampil sedangkan 13 peserta didik dinyatakan belum terampil.

Mengacu pada data yang diperoleh dapat disimpulkan keterampilan membaca pemahaman peserta didik terbilang rendah. Hal tersebut dikarenakan metode pembelajaran yang digunakan guru kurang maksimal. Guru hanya membagikan teks bacaan kepada peserta didik, peserta didik membaca teks bacaan, guru memberikan soal evaluasi terkait dengan teks bacaan, peserta didik menyelesaikan soal yang diberikan, dan terakhir guru mengoreksi atau membahas soal.

Terkait permasalahan di atas, maka alternatif yang dapat dilakukan adalah menerapkan metode pembelajaran Preview, Question, Read, Reflect, Recite, Review (PQ4R). Metode PQ4R terdiri dari enam langkah diawali dengan langkah preview (membaca sekilas), question (membuat pertanyaan), read (membaca), reflect (memahami bacaan), recite (menceritakan kembali), dan review (meninjau ulang). Alasan menggunakan metode ini yaitu peserta didik dapat membaca secara sistematis sehingga materi dapat melekat lebih lama, meningkatkan keingintahuan peserta didik, serta membuat peserta didik untuk berpikir kritis dan aktif.

Mengacu pada uraian di atas, maka peneliti tertarik untuk melakukan Penelitian Tindakan Kelas dengan judul "Penerapan Metode Preview, Question, Read, Reflect, Recite, Review (PQ4R) untuk Meningkatkan Keterampilan Membaca Pemahaman (Penelitian Tindakan Kelas pada Peserta Didik Kelas IV SD Negeri 1 Ngadirojo Lor tahun ajaran 2020/2021)"

\section{METODE}

Bagian penelitian ini dilaksanakan di SD Negeri 1 Ngadirojo Lor semester II tahun ajaran 2020/2021. Penelitian ini dilaksanakan dua siklus, setiap siklus terdiri dari empat tahap yaitu: 1) perencanaan; 2) pelaksaanaan; 3) observasi; 4) refleksi. Subjek penelitian ini adalah guru dan peserta didik kelas IV SD Negeri 1 Ngadirojo Lor tahun ajaran 2020/2021 sejumlah 15 peserta didik, sumber data berasal dari guru, peserta didik dan dokumen. Tehnik pengumpulan data yang digunakan adalah observasi, wawancara dan kajian dokumen. Tehnik uji validitas yang digunakan adalah valisitas isi. Tehnik analisis data yang digunakan meliputi: 1) pengumpulan data; 2) reduksi data; 3) penyajian data; dan 4) penarikan kesimpulan.

\section{HASIL DAN PEMBAHASAN}

Pratindakan yang dilakukan terdiri dari wawancara dan observasi. Hasil dari pratindakan menunjukkan mayoritas peserta didik dapat dikategorikan tidak terampil dalam membaca pemahaman. Hasilnya dapat dilihat di table 1 berikut:

Tabel 1. Keterampilan Membaca Pemahaman Pratindakan

\begin{tabular}{lccc}
\hline \multicolumn{1}{c}{ Kategori } & Interval & Frekuensi & Presentase \% \\
\hline Sangat Terampil & $91-100$ & 0 & 0 \\
Terampil & $81-90$ & 2 & 13,3 \\
Kurang Terampil & $71-80$ & 0 & 0 \\
Tidak Terampil & $<71$ & 13 & 86,7 \\
$\quad$ Jumlah & & $\mathbf{1 5}$ & $\mathbf{1 0 0}$ \\
\hline
\end{tabular}


Berdasarkan table di atas dapat diketahui hasil nilai pratindakan membaca pemahaman kelas IV SD Negeri 1 Ngadirojo Lor. Terdapat 2 peserta didik dalam kategori terampil, dan 13 peserta didik dalam kategori tidak terampil.

Pada siklus I, Setelah merencanakan pembelajaran dengan metode PQ4R, maka diperoleh nilai keterampilan membaca pemahaman pada table 2 berikut:

Tabel 2. Keterampilan membaca Siklus I

\begin{tabular}{lccc}
\hline \multicolumn{1}{c}{ Kategori } & Interval & Frekuensi & Presentase \% \\
\hline Sangat Terampil & $91-100$ & 2 & 13,3 \\
Terampil & $81-90$ & 1 & 6,6 \\
Kurang Terampil & $71-80$ & 1 & 6,6 \\
Tidak Terampil & $<71$ & 10 & 66,7 \\
$\quad$ Jumlah & & $\mathbf{1 5}$ & $\mathbf{1 0 0}$ \\
\hline
\end{tabular}

Berdasarkan table di atas, meningkatnya nilai peserta didik dengan pratindakan dan meningkatnya skor setiap indikatornya. Namun pada siklus I belum memenuhi indikator kinerja yang telah ditetapkan sebesar $80 \%$ peserta didik.

Hasil nilai keterampilan membaca pemahaman perlu ditingkatkan melalui beberapa aspek penilaiannya terutama aspek pemahaman isi teks yang mencakup tema, penokohan, alur, dan setting. Selain itu, ketepatan organisasi isi teks juga perlu untuk lebih ditekankan agar peserta didik mampu menceritakan secara lengkap bagian awal, inti, dan penutup cerita. Sebagian besar peserta didik juga belum memahami penulisan tanda baca dan penggunaan huruf kapital yang benar. Pemilihan kata untuk menyusun sebuah kalimat juga merupakan hal yang penting, yang mencakup pemilihan kata kegiatan dan suasana yang tepat serta pembendaharaan kata luas. Empat aspek yang perlu ditingkatkan dan diajarkan secara lebih mendalam pada siklus II adalah pemahaman isi teks, ketepatan organisasi isi teks, penulisan tanda baca dan penggunaan huruf kapital, dan ketepatan diksi.

Berdasarkan kekurangan pada siklus I, guru merencanakan dengan mengkaji ulang hasil dari siklus I. Setelah dilakukan siklus II diperolah nilai keterampilan membaca pemahaman pada siklus II pada table 3 berikut:

Tabel 3. Keterampilan membaca Siklus II

\begin{tabular}{lccc}
\hline \multicolumn{1}{c}{ Kategori } & Interval & Frekuensi & Presentase \% \\
\hline Sangat Terampil & $91-100$ & 3 & 20 \\
Terampil & $81-90$ & 9 & 60 \\
Kurang Terampil & $71-80$ & 0 & 0 \\
Tidak Terampil & $<71$ & 3 & 20 \\
$\quad$ Jumlah & & $\mathbf{1 5}$ & $\mathbf{1 0 0}$ \\
\hline
\end{tabular}

Dari data di atas, menunjukkan bahwa sebanyak 3 peserta didik atau $20 \%$ dalam kategori sangat terampil, 9 peserta didik atau $60 \%$ dalam kategori terampil. Sehingga $80 \%$ peserta didik sudah memenuhi indicator kinerja yang telah ditetapkan. Terdapat 3 peserta didik yang tidak terampil. Setelah dikaji ulang permasalah peserta didik tersebut yaitu mereka belum lancer membaca. Sehingga sulit untuk memahami dan menulis teks.

Hasil dari penelitian tindakan ini menunjukkan bahwa penerapan metode PQ4R dapat meningkatkan keterampilan membaca pemahaman pada peserta didik kelas IV 
SD Negeri 1 Ngadirojo Lor tahun ajaran 2020/2021. Dapat dibuktikan dengan peningkatan nilai setiap aspek indikator pada setiap siklusnya.

Metode pembelajaran adalah cara, langkah, atau prosedur yang disusun untuk mengimplementasikan rencana agar tujuan dapat tercapai secara optimal. Penggunaan metode pembelajaran sangat menentukan keberhasilan proses pembelajaran, bisa jadi guru menerapkan beberapa metode dalam satu pembelajaran untuk mencapai tujuan pembelajaran (Majid, 2015:193; Sanjaya, 2013:125; Suyono \& Hariyanto, 2014:19). Terdapat beberapa metode yang tepat digunakan dalam membaca pemahaman salah satunya yaitu metode PQ4R. Metode Preview, Question, Read, Reflect, Recite, Review (PQ4R) terdiri dari 6 tahap sesuai dengan kepanjangannya yaitu sebagaimana terdapat dalam buku (Nafi'ah, 2018:75-77; Suprijono, 2010:103-105; Trianto, 2014:176-178).

Menurut Shoimin (2014:190) salah satu kelebihan metode PQ4R adalah materi yang diajarkan akan lebih bermakna dan melekat pada memori peserta didik lebih lama. Hal tersebut selaras dengan hasil penelitian yang mencapai indikator kinerja peneltian pada siklus II artinya dengan penerapan metode PQ4R pada materi membaca pemahaman membuat pembelajaran lebih bermakna sekaligus peserta didik lebih aktif pada pelaksanaan pembelajaran karena peserta didik terlibat langsung dalam penerapan metode PQ4R.

Kesulitan yang dialami pada siklus I yaitu pada pengimplementasian metode PQ4R yakni pada tahap read khususnya pada siklus I, guru belum bisa sepenuhnya memusatkan perhatian seluruh peserta didik pada teks cerita karena ada beberapa peserta didik yang kurang konsentrasi sehingga mengganggu temannya. Hal ini sedikit berdampak kurang baik karena sebenarnya pada tahap read peserta didik membutuhkan konsentrasi untuk memahami keseluruhan isi bacaan. Tahap preview guru masih sulit mengkondisikan peserta didik yang belum bisa membaca untuk bersungguh-sungguh. Tahap question dan reflect, guru mengalami kesulitan dalam pengkondisian kelas karena guru tidak bertatap muka secara langsung. Tahap recite dan review tidak mengalami kendala hanya guru harus bisa membiasakan peserta didik untuk mandiri dalam mengerjakan soal evaluasi.

Sehingga hal yang dilakukan guru untuk mengatasi masalah dalam penggunaan metode PQ4R pada tahap read guru memberi motivasi kepada peserta didik untuk bersungguh-sungguh dalam membaca cerita, kemudian sebelum tahap read peserta didik diingatkan kembali tujuan pembelajaran yang akan dicapai. Tahap question dan reflect guru membuat kesepakatan dengan peserta didik bahwa akan mencatat nama-nama peserta didik yang tidak aktif saat guru memberikan pertanyaan.

- Tahap recite dan review guru mengecek dengan memanggil peserta didik untuk memantau kondisi belajar dan tugas yang dikerjakan peserta didik,

Berdasarkan hasil analisis data, pembahasan, dan dengan dikaitkan dengan penelitian yang relevan penerapan metode Preview, Question, Read, Reflect, Recite, and Review (PQ4R) dapat meningkatkan keterampilan membaca pemahaman peserta didik kelas IV SD Negeri 1 Ngadirojo Lor tahun ajaran 2020/2021.

\section{SIMPULAN}

Hasil penelitian tindakan kelas mengenai penerapan metode Preview, Question, Read, Reflect, Recite, Review (PQ4R) pada mata pelajaran bahasa Indonesia, dapat disimpulkan bahwa dengan dua siklus penerapan metode PQ4R dapat meningkatkan keterampilan membaca pemahaman peserta didik kelas IV SD Negeri 1 Ngadirojo Lor tahun ajaran 2020/2021. Penilaian keterampilan membaca pemahaman meliputi lima aspek, yaitu pemahaman isi teks, ketepatan organisasi isi teks, ketepatan struktur kalimat, penulisan tanda baca dan penggunaan huruf kapital, serta ketepatan diksi. 


\section{DAFTAR PUSTAKA}

Majid, A. (2015). Strategi Pembelajaran. Bandung: PT Remaja Rosdakarya.

Nurgiyantoro, B. (2016). Penilaian Pembelajaran Bahasa Berbasis Kompetensi. Yogyakarta: BPFE-Yogyakarta.

Saddhono, K., \& Slamet. (2012). Pembelajaran Keterampilan Berbahasa Indonesia Teori dan Aplikasi.

Sanjaya, W. (2013). Strategi Pembelajaran Berorientasi Standar Proses Pendidikan. Jakarta: Prenadamedia Group.

Shoimin, A. (2014). 68 Model Pembelajaran Inovatif dalam Kurikulum 2013. Yogyakarta: Ar-ruzz Media.

Suyitno, I. (2017). Cognitive Strategies Use in Reading Comprehension and its Contributions to Students ' Achievement Imam Suyitno, Universitas Negeri Malang, Indonesia. 5(3), 107-121.

Suyono, \& Hariyanto. (2014). Belajar dan Pembelajaran. Bandung: PT Remaja Rosdakarya.

Tarigan. (2008). Membaca Sebagai Suatu Keterampilan Berbahasa. Bandung: Percetakan Angkasa. 